\title{
DEMERSAL FISH RESOURCES RESULT OF MV. SEAFDEC 2 SURVEY IN THE SOUTH CHINA SEA OF INDONESIA
}

\author{
Wudianto ${ }^{1)}$ and Bambang Sumiono ${ }^{2)}$ \\ 1) Research Center for Capture Fisheries, Ancol-Jakarta \\ 2) Research Institute for Marine Fisheries, Muara Baru-Jakarta
}

Received November 4-2008; Received in revised form November 14-2008; Accepted November 26-2008

\begin{abstract}
The South China Sea is belonging to western part of Sunda shelf which consisted of shallow water in the southern part and deep water in the northern part area. The area of Indonesian water in the South China Sea is estimated $595,000 \mathrm{~km}^{2}$ including exclusive economic zone waters. Some fisheries activities are concentrated in coastal area especially to exploit small pelagic and demersal fish. During 2005 to 2006, a survey on estimation of demersal fish resources has been conducted in the South China Sea by using MV. SEAFDEC 2. These surveys are a collaboration research between Research Center for Capture Fisheries-Indonesia and SEAFDEC. Bottom trawl net was used as sampling equipment and swept area method was applied for estimation demersal fish abundance. During 2005, survey was carried out in the southern part area composting of 20 trawl stations which one trawl station was fails. The catch rates were varied between 11.27 and $131.6 \mathrm{~kg}$ per hour. In 2006, the location of survey shifted to the northern part area composting of 11 trawl stations. The catch rate in this cruise was found higher than that of the 2005 cruise. The lowest catch rate recorded was 37.79 $\mathrm{kg}$ per hour and the highest one was $507.71 \mathrm{~kg}$ per hour. The catch composition caught during both cruises was dominated by demersal fish species such as Lutjanidae, Ariidae, Nemipteridae, Synodontidae, Priacanthidae, and Mullidae.
\end{abstract}

KEYWORDS: $\quad$ demersal fish, abundance, South China Sea, MV. SEAFDEC 2

\section{INTRODUCTION}

The South China Sea is a continental shelf belongs to the western part of the Sunda Shelf with the average depth of $70 \mathrm{~m}$, flat bottom, and with stratification of water mass by seasons (Wyrtki, 1961). As part of the Sunda Shelf, the South China Sea is shallows water and has no plain base topography, so it is not enable to divide the column waters according to the depth. The area of South China Sea belong to Indonesia is estimated $595,000 \mathrm{~km}^{2}$ (South China Sea, 1979; Cholik et al., 1995).

Recently, the development of fisheries resources exploitation leads to a competition, since the hi-tech vessels allowed to operate in the Indonesian exclusive economic zone of South China Sea, whereas the fisheries activities are concentrated in the coastal area and in surrounding waters of several small islands. Consequently, both fishing pressure and competition among fishers for the resource in the area will increase and may accelerate conflicts among them.

The global environmental condition in this area is governed by monsoonal changes. Previous research carried out in 1978, 1985, 1994, and 2002 showed that the fish resources consisted of typical tropical shallow oceanic waters species i.e. demersal, small pelagic and shrimp resources. A few existing fishery were dominated by small pelagic fish resources which were exploited by purse seine fishery. The contribution of the pelagic catch is approximately at around $45 \%$ of total landed (Anon., 2002). A previous acoustic study carried out by Johanesson \& Mitson (1985) showed that the estimated densities as an indicator of abundance fluctuated by the season.

Recent study based on landing sites around South China Sea on all groups of demersal, small pelagic and crustacean species and estimated trough surplus production models showed that the resources has already heavily exploited (Arion., 2006). To clarify and updating these phenomenon as a part of national program on fish stock assessment, the information seems to be reevaluated through in situ on board observation. The recent and modern research equipment installed on M. V. SEAFDEC 2 was available to be used as a platform on this program. This paper presented the demersal fish resources as results of M. V. SEAFDEC 2 survey which were conducted in 2005 and 2006.

The objectives of this study were as follows 1) to identify the distribution and abundance of demersal fish resources; 2 ) to identify the catch composition of demersal fish; and 3) to observe some biological parameter of some demersal fish with emphasize on size of fish. 


\section{MATERIALS DAN METHODS}

\section{Survey Area and Cruise}

Geographic location of the research area is shown in Figure 1 for cruise in 2005 and Figure 2 for cruise in 2006 . The main survey area is characterized by inshore and offshore waters. Several small islands with there surrounding area were belonging to untrawlable grounds. The cruises were designed as a standard parallel transect for acoustic and bottom trawl survey.

Figure 1 and 2 show that during 2005 survey the site of study located in the southern part area, whereas during 2006 survey the area of study shifted to the northern part area. In 2005 and 2006, the duration of survey was 20 days (from 12 June to 3 July 2005) and 13 days (from 10 June to 23 June 2006) including bunkering and replenishment, respectively.

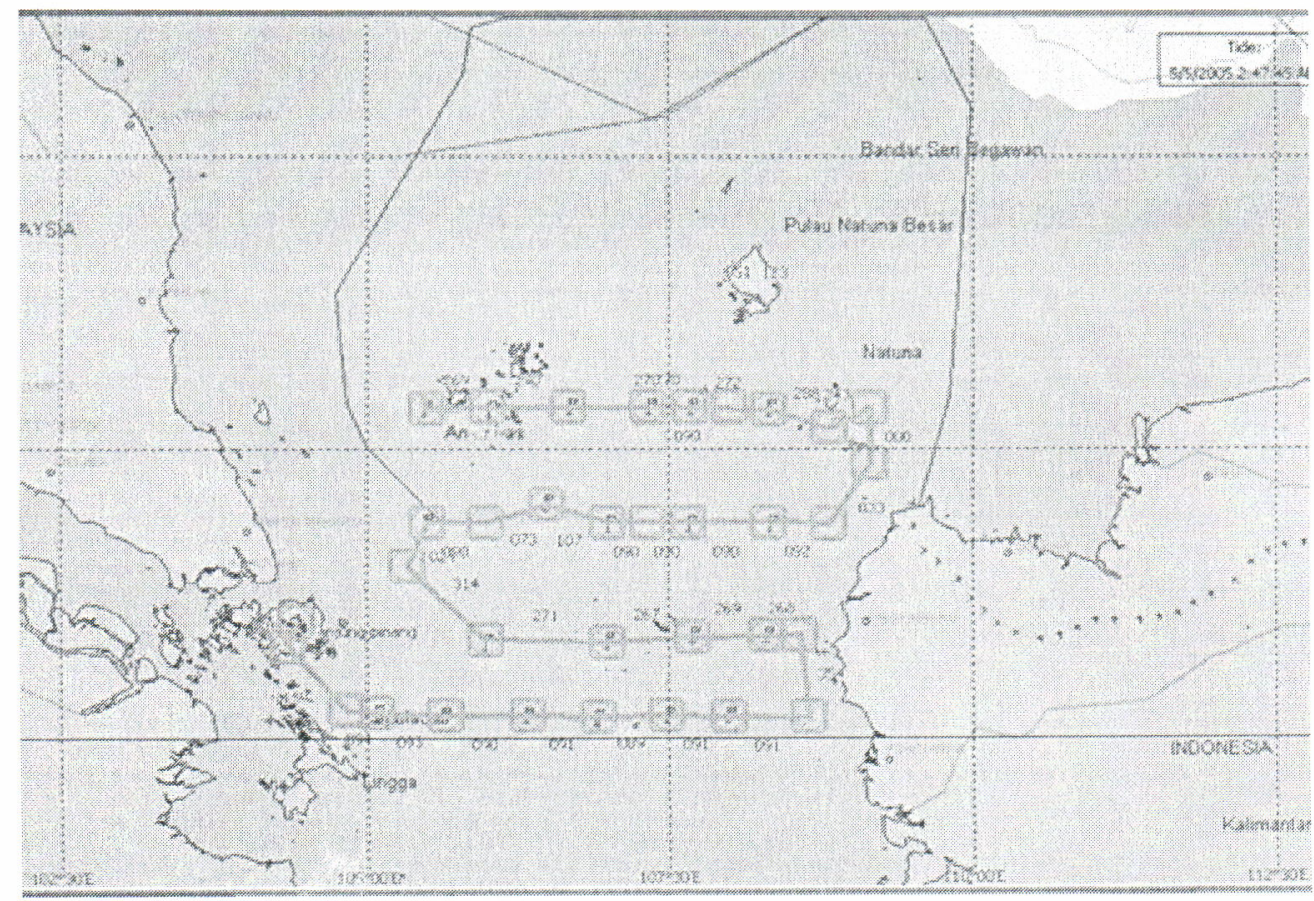

Figure 1. Map of survey area by M. V. SEAFDEC 2 in South China Sea Indonesia, June 13 - July 2, 2005.

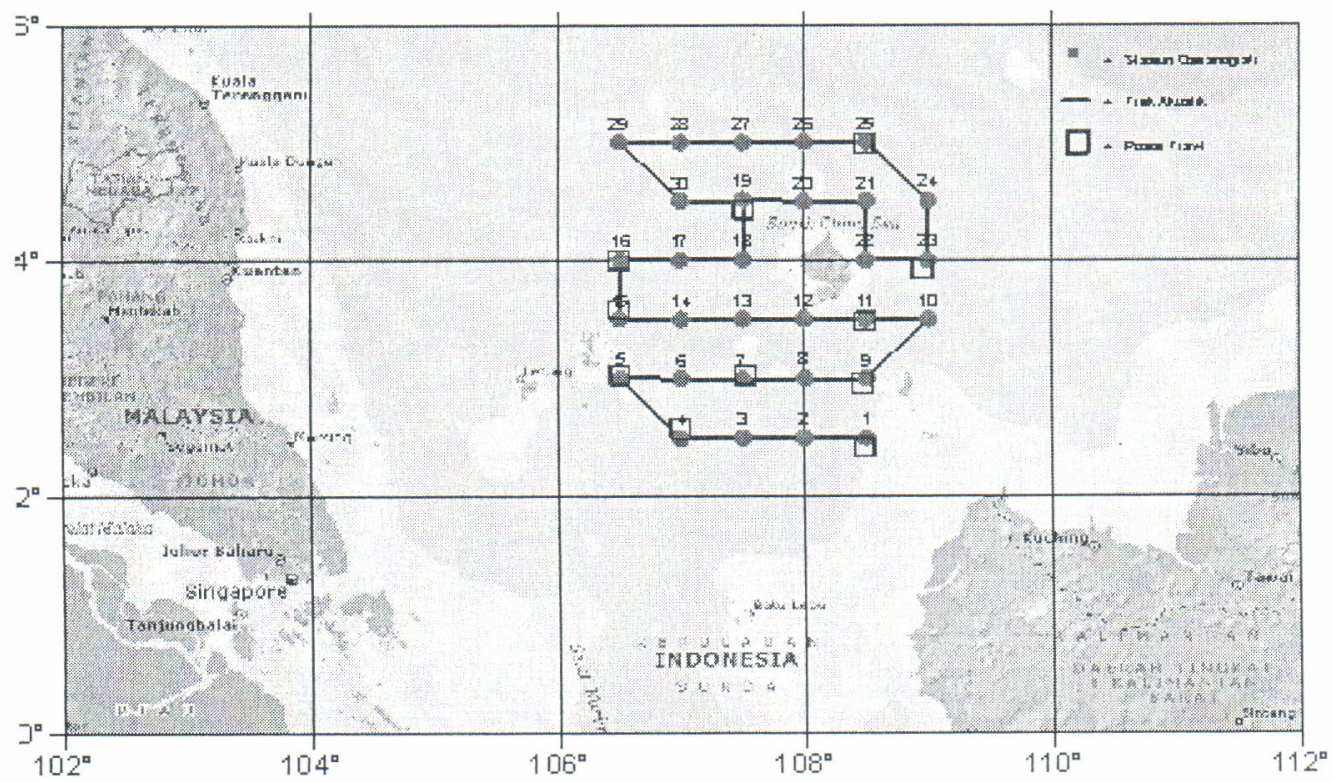

Figure 2. Map of survey area by M. V. SEAFDEC 2 in South China Sea, Indonesia, 10 to 23 June 1013, 2006. 


\section{Research Vessel and Equipments}

The cruises were carried out using the research vessel M. V. SEAFDEC 2, with specification is a 207 gross tonnage, $32.5 \mathrm{~m}$ in length, and $7.2 \mathrm{~m}$ in wide. The gear and equipments used were fisheries acoustic instruments, bottom trawl fishing, squid jigging, bongo paired plankton net and oceanographic equipments. Bottom trawl net of $17.30 \mathrm{~m}$ in head rope was used, with mesh size for cod end of $60 \mathrm{~mm}$ as shown in Appendix 1.

\section{Methodology}

The position of sampling stations were set up systematically along the latitude on the hydro acoustic transect lines. Prior to each trawling station an oceanographic survey was carried out. In 2005, a total of 20 trawl fishing, 20 oceanographic sampling stations, and 20 larval stations have been completed. From total of 20 trawling stations, one trawl fishing should be considered unsuccessful due to some technical problems. The otter boards were upside down during the towing of the nets, which resulted in the improper opening at trawl mouth. During 2006 the survey has been carried out on 11 trawling stations 30 oceanographic stations, and 30 larvae sampling stations.

Trawl net was towed in one hour duration at the vessel speed of 3 knots. Fish catches were sorted and weighted. Sorting of fish were carried out whenever possible until species level, genus or family (Fisher \& Whitehead, 1974; Tarp \& Kailola, 1984; Mansoor et al., 1998; Carpenter \& Volker,1998; Grey \& Dall,1983; Holthuis, 1991). Catch data in the form of weight and number were filled into a fishing log sheet. The length and weight frequency measurements were done to some relatively dominant species.

Swept area method was applied to estimate demersal fish abundance which is indicated by catch per unit effort (catch per hour trawling) (Shindo, 1973; Saeger et al., 1976).

\section{RESULTS AND DISCUSSION}

\section{Catch Rate}

Catch rate could provide as indicator for the index of abundance of fish resources. During cruise 2005, the lowest catch rate of about $11.27 \mathrm{~kg}$ per hour was occurred at the station number 7 , while the highest catch rate was occurred at the station number 13 . The summary of the catch rates during 2005 cruise is presented in Table 1, and the distribution of catch rates are illustrated in Figure 3.

The relatively high variation in catch rate indicate that the distribution of demersal fish resource in this area during the survey periods was somewhat forming cluster. This was likely due to the occurring differences in bottom substrate. In the central area of the southern part of South China Sea, the bottom substrate was dominated by giant cup sponges (Poterion sp.) mix with some life corals. This was indicated by the occurrences of the butterfly fish, Coradion sp. of the family Chaetodontidae.

Table 1. Summary of the catch rates of demersal fish caught using bottom trawl in the South China Sea-Indonesia, June 13 - July 2, 2005

\begin{tabular}{lclc}
\hline \multicolumn{1}{c}{ Items } & Quantity & \multicolumn{1}{c}{ Items } & Quantity \\
\hline Total No. of trawl station & 20 & Mean of catch rate $(\mathrm{kg} / \mathrm{hr})$ & 57.9 \\
Minimum catch rate $(\mathrm{kg} / \mathrm{hr})$ & 11.27 & Standard deviation & 34.8 \\
Maximum catch rate $(\mathrm{kg} / \mathrm{hr})$ & 131.6 & Coefficient of variation $(\%)$ & 60.0 \\
\hline
\end{tabular}

In 2006 cruise was carried out in 13 trawling stations with catch rates fluctuated from $37.79 \mathrm{~kg}$ per hour to $504.71 \mathrm{~kg}$ per hour with an average of 216.96 $\mathrm{kg}$ per hour as shown in Table 2. Spatial distribution of catch rates are illustrated in Figure 4.

Figure 4 show that the high abundance of fish was found in the southeast part of South China Sea where this area is shallower than the northern part area.

\section{Catch Composition}

A total of approximately 149 species of bony fish and elasmobranch, three species of cephalopod, five species of crustacean including shrimp, and lobsters has been recorded. Some fish groups which were considered as trash fish and number of sea snakes were also counted. The dominant fish family caught during 2005 and 2006 cruises are listed in the Table 3 and 4. 


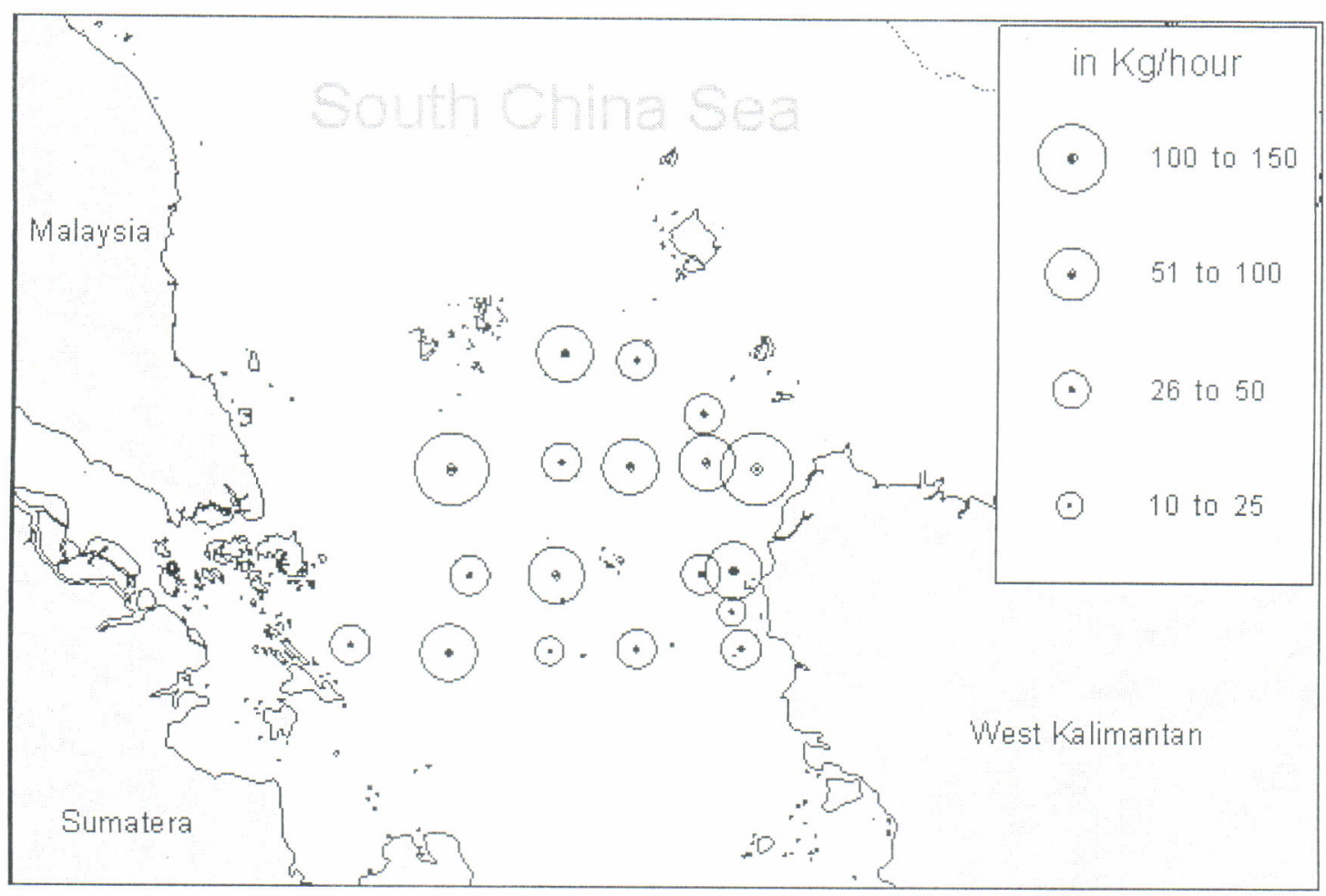

Figure 3. Distribution of catch rate (kg per hour) in the survey area during 2005.

Table 2. Summary of the catch rates of demersal fish caught USING bottom trawl in the South China Sea-Indonesia, June $10-23,2006$

\begin{tabular}{lclc}
\hline \multicolumn{1}{c}{ Items } & Quantity & \multicolumn{1}{c}{ Items } & Quantity \\
\hline Total No. of trawl station & 11 & Mean of catch rate $(\mathrm{kg} / \mathrm{hr})$ & 216.96 \\
Minimum catch rate $(\mathrm{kg} / \mathrm{hr})$ & 37.79 & Standard deviation & 132.22 \\
Maximum catch rate $(\mathrm{kg} / \mathrm{hr})$ & 504.71 & Coefficient of variation $(\%)$ & 60.0 \\
\hline
\end{tabular}

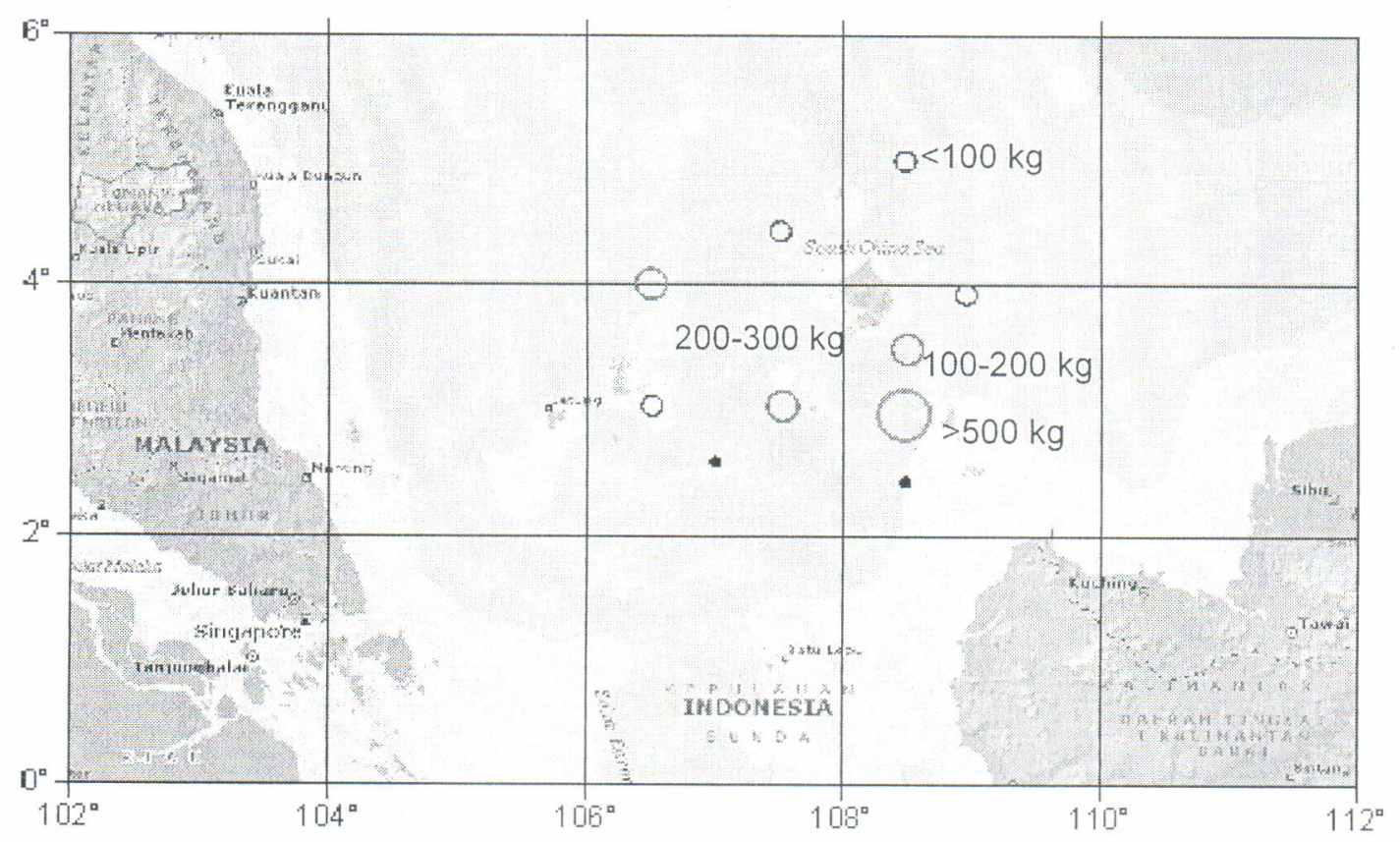

Figure 4. Distribution of catch rate (kg per hour) in the survey area during 2006. 
During 2005 cruise, most of fish caught was dominated by sharks and rays. Within this group the species of Dasyatis kuhlii and Himantura gerrardi provide the most dominant. The second dominant fish group was catfish (Ariidae) and snappers (Lutjanidae). Catfish group was dominated by Arius venosus and A. thallasinus, while snappers group were dominated by Lutjanus johni and Lutjanus vittus.
During 2005 survey, the third dominant group i.e., threadfin bream (Nemipteridae), anchovies (Engraulidae), and goatfish (Mullidae) were caught by trawl net. The threadfin bream group was dominated by Scolopsis taeniopterus and Nemipterus nematophorus. Anchovies group was dominated by Stolephorus indicus, while goatfish were dominated by Upeneus sundaicus and U. sulphureus.

Table 3. The dominant fish caught using trawl during survey in 2005

\begin{tabular}{clccclcc}
\hline No. & Fish group & Weight $(\mathbf{k g})$ & $\%$ & No. & Fish group & Weight $(\mathbf{k g})$ & $\%$ \\
\hline 1. & Sharks and Rays & 259.6 & 24.9 & 8. & Balistidae & 33.3 & 3.2 \\
2. & Ariidae & 90.7 & 8.7 & 9. & Gerreidae & 32.3 & 3.1 \\
3. & Lutjanidae & 84.4 & 8.1 & 10. & Synodontidae & 30.2 & 2.9 \\
4. & Nemipteridae & 62.5 & 6.0 & 11. & Serranidae & 22.9 & 2.2 \\
5. & Engraulidae & 58.4 & 5.6 & 12. & Squids & 41.7 & 4.0 \\
6. & Mullidae & 58.4 & 5.6 & 13. & Miscellaneous fish & 162.8 & 18.8 \\
7. & Carangidae & 37.5 & 3.6 & 14. & Trash fishes & 67.7 & 6.5 \\
\hline
\end{tabular}

Table 4.

The dominant fish caught using trawl during survey in 2006

\begin{tabular}{clcccccc}
\hline No. & Fish groups & Average $(\mathrm{kg} / \mathrm{hr})$ & $\%$ & No. & Fish groups & Average $(\mathrm{kg} / \mathrm{hr})$ & $\%$ \\
\hline 1. & Lutjanidae & 20.40 & 9.40 & 9. & Caesionidae & 8.05 & 3.71 \\
2. & Nemipteridae & 18.41 & 8.49 & 10. & Gerreidae & 7.64 & 3.52 \\
3. & Synodontidae & 14.26 & 6.57 & 11. & Leiognathidae & 6.97 & 3.21 \\
4. & Priacanthidae & 13.67 & 6.30 & 12. & Serranidae & 4.02 & 1.85 \\
5. & Carangidae & 13.64 & 6.29 & 13. & Sharks & 3.37 & 1.56 \\
6. & Mullidae & 13.55 & 6.25 & 14. & Lethrinidae & 3.37 & 1.55 \\
7. & Ariommatidae & 8.38 & 3.86 & 15. & Trash fish & 8.07 & 3.72 \\
8. & Pentapodidae & 8.10 & 3.73 & & & & \\
\hline
\end{tabular}

Other relatively dominant fish group were trevallies (Carangidae), trigger fish (Balistidae), silver biddies (Gerreidae), lizard fish (Synodontidae), and groupers (Serranidae). The trevallies were dominated by Carangoides malabaricus, trigger fish by Abalistes stellaris, silver biddies by Pentaprion longimanus, lizard fish by Saurida micropectoralis and groupers by Plectropomus malabaricus.

Other economically important fish group with percentage of less than $2 \%$ of total catch were Spanish mackerels (Scombridae, Scomberomorous commerson), bulls eyes (Priacanthidae, Priacanthus macracanthus), sweetlips (Pomadasydae, Plectorynchus pictus), black pomfrets (Formionidae, Formio niger), emperors (Lethrinidae, Lethrinlis lentjan), slipmouth (Leiognathidae, Leiognathus elongatus and L. bindus), and baraccudas (Sphyraenidae, Sphyraena jellow, and S. obstusata).

Some of pelagic fish of the family Carangidae such as round scad (Decapterus maruadsi and Decapterus akaadsi), yellow strip trevallies (Selaroides leptolepis) and big eyed scad (Selar chromenopthalmus) were found in a very small quantity. Other pelagic fish such as chub mackerels (Rastrelliger kanagurta) was also found in very small quantity.

Other non fish biota which was caught in substantial quantity was the squids and cuttle fish group. Squids were dominated by Loligo edulis and Loligo singhalensis, while cuttle fish group by Sepia aculeata. It was very few number of penaeid shrimp were caught in this area that are only three specimens of shrimp i. e. endeavour shrimp (Metapenaeus endeavouri), coarse shrimp (Trachypenaeus granulosus and Trachypenaeus asper) were found. Crustaceans group was dominated by flathead lobster (Thenus orientalis) and two specimens of ornate spiny lobster (Panulirus ornatus)

Similar result was also found during 2006 survey as shown in Table 4, the dominant catch were occupied by families of Lutjanidae, Nemipteridae Priacantidae, Synodontidae, Carangidae, and Mullidae. 
Table 5. Total length of some demersal fish during survey in 2005

\begin{tabular}{lccccccc}
\hline No. Species & $\begin{array}{c}\text { TL range } \\
(\mathrm{cm})\end{array}$ & $\begin{array}{c}\text { No.of } \\
\text { sample }\end{array}$ & No. & Species & $\begin{array}{c}\text { TL range } \\
(\mathrm{cm})\end{array}$ & $\begin{array}{c}\text { No.of } \\
\text { sample }\end{array}$ \\
\hline 1. Pentaprion longimanus & $4.5-20.0$ & 515 & 5. & Nemipterus tambuloides & $5.0-18.0$ & 204 \\
2. Upeneus sundaicus & $6.0-19.0$ & 404 & 6. & Pterocaesio chrysozonus & $5.0-14.0$ & 162 \\
3. Scolopsis taenoptera & $10.0-24.5$ & 332 & 7. & Upeneus luzonius & $6.0-13.5$ & 150 \\
4. Upeneus sulphureus & $4.0-18.0$ & 294 & 8. & Pentapodus setosus & $9.0-19.0$ & 121 \\
\hline
\end{tabular}

Table 6. Total length of some demersal fish during survey in 2006

\begin{tabular}{|c|c|c|c|c|c|c|c|}
\hline No. & Species & $\begin{array}{l}\text { TL range } \\
(\mathrm{cm})\end{array}$ & $\begin{array}{c}\text { No.of } \\
\text { sample }\end{array}$ & No. & Species & $\begin{array}{l}\text { TL range } \\
(\mathrm{cm})\end{array}$ & $\begin{array}{l}\text { No.of } \\
\text { sample }\end{array}$ \\
\hline 1. & Pentaprion longimanus & $8.0-12.5$ & 100 & 7. & $\begin{array}{l}\text { Nemipterus } \\
\text { nematophorus }\end{array}$ & $7.0-23.0$ & 87 \\
\hline 2. & Priacanthus macracanthus & $11.0-26.0$ & 266 & 8. & Nemipterus marginathus & $17.0-27.5$ & 34 \\
\hline 3. & Leiognathus bindus & $5.5-10.5$ & 264 & 9. & Nemipterus bathybus & $9.5-19.5$ & 257 \\
\hline 4. & Leiognathus cf aureus & $6.0-10.0$ & 164 & 10. & Scolopsis tayenopterus & $17.0-26.0$ & 26 \\
\hline 5. & Upeneus bensasi & $7.0-17.5$ & 296 & 11. & Saurida undosquamis & $19.5-26.0$ & 24 \\
\hline 6. & Upeneus moluccensis & $6.0-19.5$ & 304 & 12. & Saurida micropectoralis & $19.5-26.0$ & 6 \\
\hline
\end{tabular}

\section{Length of Fish Frequency}

A total of 3,188 individual fish from 35 species has been measured. The ten most dominant measured fish are listed in the following Table.

Table 5 and 6 indicated that most of demersal fish species caught by trawl net during those cruises were found in small size. From this phenomenon could roughly conclude that some demersal fish species in the South China Sea were already fully exploited.

\section{CONCLUSSIONS}

1. The distribution of catch rate for demersal fish indicated that the higher fish abundance was observed in the northern water area of the South China Sea. The northern area was deeper water comparing with the southern part area.

2. The catch composition during 2005 cruise survey was dominated by families Ariidae, Lutjanidae, and Nemipteridae. It is slightly different with catch composition in 2006 cruise survey that was dominated by Lutjanidae, Nemipteridae, and Synodontidae.

3. Some of demersal fish caught in small sizes, this phenomenon indicated that the fish resources have been fully exploited.

\section{ACKNOWLEGMENT}

We would like to thank to all the team members of M. V. SEAFDEC 2 survey during 2005 and 2006 cruise for helping to collect the data. This survey was conducted based on the research collaboration between Research Center for Capture Fisheries and SEAFDEC.

\section{REFERENCES}

Anonymous. 2002. Capture fisheries statistics of Indonesia 2001. Directorate General of Capture Fisheries. Ministry of Marine Affairs and Fisheries. Jakarta.

Anonymous. 2006. Capture fisheries statistics of Indonesia 2005. Directorate General of Capture Fisheries. Ministry of Marine Affairs and Fisheries. Jakarta.

Carpenter, K. E. \& H. N. Volker (Eds). 1998. The living marine resources of the Western Central Pacific. Vol.2. Cephalopods, Crustaceans, Holothurians, and Sharks. F. A. O. Rome. Italy.

Cholik, F., M. F. Sukadi, S. Nurhakim, I. G. S. Merta, \& J. Widodo. 1995. Evaluasi pengkajian sumber daya perikanan laut. Pusat Penelitian dan Pengembangan Perikanan. Badan Penelitian dan Pengembangan Pertanian. 15 hal. (in Indonesian).

Fischer, W. \& P. J. P. Whitehead. (Eds.). 1974 Species identification sheet for fishery purposes. Eastern Indian Ocean (Fishing Area 57) and Western Central Pacific (Fishing Area 71). Vol.IIV. F. A. O. Rome. Italy.

Tarp-Gloerfelt, T. and P. Kailola., 1985. Trawled fish of the southern Indonesia and northern Australia . ADAB -GTZ-DGF Indonesia. 406 p. 
Grey, D. L. \& W. Dall. 1983. A guide to the Australian penaeid prawn. Department of Primary Production. Darwin. Northern Territory.

Holthuis, L. B. 1991. F. A. O. Species Catalogue. Vol.13. Marine Lobster in the World. An annotated and illustrated catalogue of species of interest to the fisheries known to date. F. A. O. Fisheries Synopsis. No.125. Vol.13. F. A. O. Rome. 292 p.

Johanesson, K. A. \& R. B. Mitson. 1985. Fisheries acoustic: A pratical manual for aquatic biomass estimation. F. A. O. Fishery Tech. Paper. No.240. Rome. 249 p.

Mansoor, M. I., K. H. Ida, Nakamura H. T., Asnan Z., \& Abdullah. S. 1998. Field guide to important commercial marine fishes of the South China Sea. SEAFDEC MFRDMD/SP/2.
Saeger, J. P., P. Martosubroto, \& D. Pauly. 1976. Fish report of the Indonesia German demersal fisheries project. Result of a trawl survey in the Sunda Shelf area. Laporan Penelitian Perikanan Laut No. 1:146.

South China Sea. 1979. Report of workshop on demersal and pelagic fish resources in the Java Sea. SEAFDEC. South China Sea (Gen/79/20). $19 \mathrm{p}$.

Shindo, S. 1973. General review of the trawl fisheries and the demersal fish stock of the South China Sea. F. A. O. Fishery Tech. Pap. No.120. F. A. O. Rome.

Wyrtki, K. 1961. Physical oceanography of the south east Asian waters. Naga Report. 2. $195 p$ 
Appendix 1. Design of bottom trawl used for demersal fish sampling

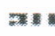

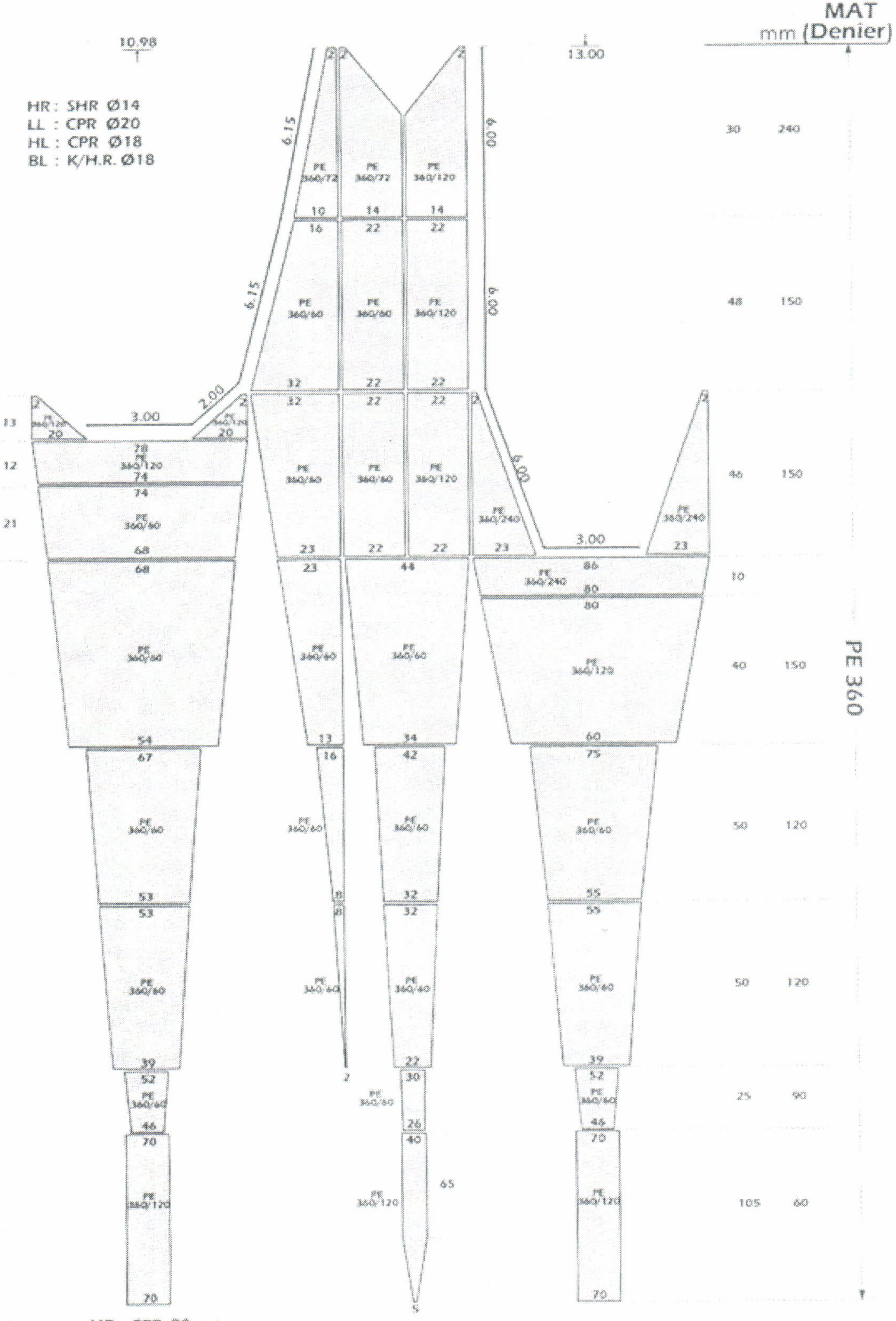

Mr: $\mathrm{CPR} 20 \mathrm{~mm}$

BR: CPR $16 m m$ 